$\begin{array}{llll}37.1^{\circ} \mathrm{C} \sim 37.5^{\circ} \mathrm{C} & 13 \text { 例 } & 16 \text { 例 } & 10 \text { 例 } \\ 27.6^{\circ} \mathrm{C} \sim 38.0^{\circ} \mathrm{C} & 5 \text { 例 } & 3 \text { 例 } & 0 \\ 38.0^{\circ} \mathrm{C} \text { 以上 } & 6 \text { 例 } & 3 \text { 例 } & 0\end{array}$.

術後24㭙間，最も多いのが $37.5^{\circ} \mathrm{C}$ 迄の微熱である. 8.3 $0^{\circ} \mathrm{C}$ 以上の発熱をみるものも文相当にある. 48時間後 は下熱の傾向はあるが微熱は引続き存続し，72時間後 に至つて殆どが $36^{\circ} \mathrm{C}$ 代となる。

\section{出血と発熱との関係 :}

手術時出血量は癒着强度のものに比較的多いが， 38 . $0^{\circ} \mathrm{C}$ 以上の発熱をみた患者 6 例中 3 例は手術時出血多 量のものであり，後の 3 例は後出血を来した患者であ る.

総

\section{後出血:}

現在まで扁䄻剔出を行つた総ての患者中，3 例に後 出血，2 例に痌桃周囲，軟口䒸の血腫北成をみた。血 腫の為いずれも䜩下，呼吸の障害を来したが，72時間 後には吸収された。年令は15才 1 例，後は20才〜40才 性別は男性である. 以上 5 例中，筋障害 2 例，腎炎 患者 1 例, 単なる慢性扁桃炎患者 2 例, である。扁桃 剔出を行つた心筋障害患者は13例，腎炎患者20例であ り，手術例数吕比較的少小にか〉わらず，単なる扁桃 肥大，または慢性啢桃炎患者に比べ術後合併症がはる かに多くなつている.

括

扁桃性病晕感染㭧者の未焇血白球百分率に於て，リンパ球の比較的增加を認め，屚桃剔出手術に より 2 週後には，ほぐ正常值に復帰した，プラスマ細胞を認める患者が少数ながら存する。

扁桃剔出手術後，多数のもの分 $37^{\circ} \mathrm{C}$ 代の発熱を来す。中には $38^{\circ} \mathrm{C}$ 以上の発熱をみるものもあるが 72時間後にはほとんどが下熟する，発熱の程度と術中，術後の出血量とは関係ある様で，多量出血 したものに高熱の出るものが多い。

後出血または口蓋血腫等の術後合併症は, 心筋障害, 腎炎, 等の血管系に病変を有する患者に比 較的多く認められる。これら患者の手術に当つては充分な注意を要する.

擱筆するに臨み，恩師後藤教授の御校閲を賜つた事に深謝します。

\section{交}

1）佐藤；血球の見方々診断の附け方 昭 19

2) 清川；日循環器 $12 ; 78$.

3). Gutzelt u Parade; Exgeb. der innere :

Med. u. Kind. 57; 1939

4）小泉；日循環器 $6 ; 187$

5）大藤；九大 $\mathbf{6} ; 4$
献
6）尾銭；耳鼻臨 $31 ； 3$
7）頭司；日耳鼻 $\mathbf{5 0 ； 9}$
8）西川；日耳鼻 $\mathbf{5 5}$; 550
9）安東; 感染と免疫 昭 28
10）西村；医学研究 $19 ; 6430$
11）西村；日耳鼻 $\mathbf{5 2} ; 8287$

\title{
妊婦に見られた出血性の喉頭炎と重曹注射の効果
}

堀 内 邦 夫*

最近妊娠 6 力月の业人に発現した㾓皮形成を伴う出血性の喉頭炎を観察し, 之に対しで重曹水静 注が卓效を泰した一症例を経騟したので報告すする。

症

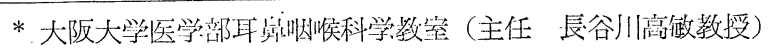

例 
患者：川○美○子 우 26才 主婦

初診：昭和 31 年 2 月 8 日

主訴：高度の榎声および喉頭痛

家族歴：既往歴：共に特記すべきものなく生来健康 で一児の母, 現在第 2 回妊娠の 6 力月目である.

現病歴: 約 1 週間前より感冒気味で, 軽度の発熱, 喉頭痛，咳嗽があつた，2〜3日前よりさらに嗄声を来 し日を逐うて増強して来た。

全身所見：体格栄養中等度，体温 $37.8^{\circ} \mathrm{C}$ ，胸部聴診 上軽い笛声音を認め，急性気管支炎の所見を呈した。 心音，腱反射共に正常．尿蛋白，糖共に陰性，寄生虫 卵検查陰性.

局所所見 : 耳，鼻に異常無く，咽喉部は全般的に軽 度発赤。䐅頭粘膜も喉頭蓋，披裂軟骨部，仮声帯，喉 頭下腔にわつて発赤および軽度の腫脹を認めるが，運 動麻痺は認められなかつた。

経過 : 以上の所見から感冒に起因した急性喉頭気管 支炎の診断のもとに，ルゴール氏液の塗布，重曹食塩 水の吸入を行うとともに，抗生物質療法として油性ぺ ニシリン総量 60 万単位, アクロマイシン $2 \mathrm{~g}$ 用いたと ころ，気管支炎症状は速かに消褂し，㩔頭痛および嗄
声もまた著しく軽快したので，2月15日，自宅で吸入 を行う様指示して通院を中止した。とこうが 3 月 1 日 に到り，再び夏声の増強と血痰の喀出を訴えて来院し た.

再診時の全身状態は体温平熱，食欲良好，胸腹部に 全く理学的所見を認めなかつた。

局所所見は初診時と異り，咽頭後壁，㩔頭蓋は発赤 乾燥し, 血管の怒張を認め, 両側声带は暗赤色で高度 に乾燥し，黒褐色の痂皮で被われ，気管粘膜もまた乾 燥し，所謂喉頭オツエーナの所見を示したが，声帯麻 痺は認めなかつた。

治療として, ルゴール氏液塗布, 重塩水吸入を行い つつ経過を観察したが，自覚的には嗄声増强し，他覚 的には出血ならびに痂皮形成高度となつて来たので， 3 月 4 日試みに $7 \%$ 重曹水 $50 \mathrm{cc}$ の錚注を行つたとこ ろ, 翌日には血痰の喀出は止み, 夏声は著しく軽快し， 他覚的にも声帯部の痂皮の消失を認めた。そ放後連日 重曹注射を行い第 4 回目に到つて，嗄声は全く認めら れず，喉頭所見を正常に復した．以後再発することな く7月 3 日に無事出産した.

\section{総括 及び考按}

本症例は，妊娠性の喉頭障害の素地を有する婦人 が，感冒に䍜患することによつて症状増悪を来したも の, 若しくは, 感冒が妊娠性喉頭变化の発現の誘因々 なつたものと考えられる. 而して，抗生物質療法によ つて治瘾せしめ得なかつたが，高濃度重曹水注射によ つて速かに治瘾せしめ得た症例である。

妊娠と知頭障害については，松田教授の宿題報告を はじめ, 吉村, 増田, 原, 久保, 姉小路氏等の報告が あり, 喉頭の他覚的所見として, 粘膜の発赤腫脹, 乾 燥性变化，痂皮形成，出血，搌頭㧍よび気管のオツエ 一ナ，声带麻痺等があげられ，自覚症状として嗄声お よび呼吸困難が述べられている.しかしてその本態に ついては妊娠時の内分泌機能低下, 或は妊娠中毒症,

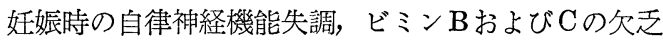
等が言われ，治療としてホルモン療法，ビタミン療法 等が試みられている。 また，姉小路氏は妊娠の嗄声お よび呼吸困難が人工流産によつて速かに治瘾した症例 を報告している.

私は，本症例に於ける㑨頭病変は，妊娠にもとづく 自律神経機能障害の結果起つた血管神経症を有する患 者が感冒に罹患することによつて喉頭症状の発現ない しは増覀を来したものであり, 従つて血管痓攣の緩解 作用を有する $7 \%$ 重曹水の静注が卓効を奏したもので あると解釈している．妵娠時に使用法の難かしいホル モン療法や，人工流産の如き手段に到る前に，安全か つ効果的な重曹注射を一応試みるべきである.

論

妵娠 6 カ月の婦人に起つた痂皮形成著明㳊出血性の喉頭炎で高度の嗄声を訴える一症例を観察 し，7\%重曹水の静注が卓效を有することを㤎めた。即ち第 1 回注射の翌日には嗄声著しく軽快し， 他覚的にも痂皮の消失を認め，総計 4 回の注射によつて完全に治癒し以後再発することなく無事に 出産した。

本論文の要旨は第84回大阪地方会に於て発表した. 
（稿を終るに臨み御指尊ならびに御校閲を頂いた恩師長谷川教授に深甚の謝意を表します）

交

1）長谷川高敏：重曹注射の臨床的効果; 昭29

2）前田春雄, 上善微雄; 耳喉科 $28 ； 6$;

3）.松日竜一日耳鼻 44; 12. 治及処 19; 5，6，7

4）増田信一郎；耳喉科 $\mathbf{9} ; 7$,
献

5）久保正雄；耳鼻臨床 38; 3,

6) 姉小路理; 耳喉科 21 ; 3 ,

7) 原薰; 耳唤科 $21 ; 8$,

\section{誤燕魚骨の迷走せる 1 症例}

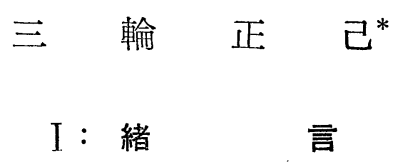

䛊嬹による咽頭異物は日常我乃のよく遭遇するもので，その発見も左程難事とは思われないが， しかし尖鋭細小なものが多いために数多くの症例のうちには異物が見当らず困却する場合が少くな い、なかんずく，異物が当初発見されずに放置された為に迷走移動する場合は，一見，無関係な症 状を呈し診断を愦らせるものである.

私は, 最近, 2 カ月間の長きに亘り, 再々左頡下部の腫脹, 圧痛を繰返し, その都度抗生物質に よつて一応治癒をみて来たが，遂に切開する事によつて，測らずもそれが䛊㫶魚骨の迷走移動に由 来したものであつた症例を経験したので報告する。

II : 症

患者 : 柳 $\bigcirc$ 是 66 才 古

主䚺：左顎下部の腫脹，圧痛および燕下困難，觾下 痛 (特に左側が著明)

既往歴, 家族歴 : 特記すべきことはない.

現病歴: 昭和 32 年 4 月上旬, 夕食時, 焼いた「太刀 魚」の骨を䛊與し，燕下痛（特に左側に著明）が消社退 しない為に 3 日後に某診療所を訪れたが，異物は見出 されず下咽頭後壁に発赤腫脹があると云われ，薬夜の 咽頭塗布を受けていた。しかるに10日後に至り，左頡 下.部の圧痛腫脹に初めて気付き漸次䓵下痛が増強して 掑食不能となり，たぐ少量の水のみ瞣下可能の状態に なつた。そこでオーレオマイシンを 5 日間服用して圧 痛, 腫脹が減退し，揕食可能とはなつたが，倦念感が とれなかつた。ところが 5 月上旬に至り，再び左顎下 部の圧痛腫脹をみ，䜩下痛を訴え，掑食不能となつた が，今度は早期にオーレオマイシンを服用 (3 日間)

\section{例}

して該障害が去り摃食可能となつたので放置していた ところ，また $4 \sim 5$ 日前より再で拱食可能となり漸次 衰弱するので 6 月 4 日第一日赤耳鼻科を訪れ同日入院 した.

\section{初診時所見：}

一般所見 : 体格中等度, 栄養や>不良, 䈍瘦著明, 顔貌は活気なく, 全身及皮膚乾燥し, 可視粘膜は貧血 性, 平温平脈で胸腹部に鼠瘦を認めるが諸臓器に異常 はみられない。

局所所見：左藚下部に母指頭大の腫瘤を触れるが， 表面は平滑, 芝膚との瘾着なし, 硬度は弾性硬, 圧痛 著明（上部一放散性）にして頭運動は疼痛の為に障害 されて軽度の咬痓をみる。咽頭粘膜は一般に軽度充 血, 口蓋扁桃に膿栓を認める他には著変なく, 勿論ど こにも霬孔を認めず排膿も見られない。㗹頭注異常な く榎声，呼吸困難もない，以上の所見よりリンパ腺腫

京都府立医科大学耳鼻咽喉科教室（主任 中村文雄教授）

京都第一赤十字病院耳鼻咽呢科（主任 菅野正雄医長） 